\title{
The Roles of Malays in the Process of Islamization of the Malay World: A Preliminary Study
}

\author{
Mohd Noh Abdul Jalil1 \\ ${ }^{1}$ Department Usuluddin and Comparative Religion, International Islamic University Malaysia \\ Email: mohdnoh@iium.edu.my
}

Accepted Article: 20 August 2014

Published Article: 20 April 2015

\begin{abstract}
This paper will deal with problem concerning issues and theories of Islamization of the Malay world, with particular reference to the absence of the important element in these theories, which is the role and contribution of the Malay towards the process of Islamization in this region. Furthermore, there will be a discussion of the problem of generalization of existing theories, as well as issues concerning the limited amount of local evidence to support these theories. Sources for this analysis will be taken from studies of inscriptions, as well as early Malay text, religious and non-religious texts. Comparison between the existing theories and direct and indirect evidence from sources will be used to ebolerate this matter. The ability of the early Malays to adopt and adapt foreign practices suggest that they also contributed to the entire process of Islamization of the Malay world one way or another.
\end{abstract}

Keywords: Islamization, Malays, Role, Contribution

\section{A. INTRODUCTION}

The formulation of comprehensive theories related of the coming of Islam to the Malay world has attracted many scholars to come out with with arguments and counter arguments to validate various approaches and interpretation. The generally peaceful penetration of Islam into the Malay world which is not questioned, was in contrast to other areas such as the indian subcontinent, and the fact that the gradual change of the religious adherence among the Malays at that time from hindubuddhist religions to Islam invited more interesting and yet unanswered questions to be explored. Broadly speaking, one can discern two major approaches by their differing emphasis on faith or facts. The former seems to be upholding a faith-based theory which requires less factual evidence to support their claims.

\section{B. METHODS}

This article is a discussion on the existing theories of Islamization in the Malay world, as well as issues concerning the limited amount of local evidence to support these theories. Sources for this analysis will be taken from studies on texts, including the early Malay texts, either religious or nonreligious. Comparison between the existing theories and direct and indirect evidence from sources will be used to ebolerate this matter. 


\section{RESULT AND DISCUSSION}

\section{Theories of The Islamization of the Malay World}

The best example of a faith-driven approach is the resolution which was formulated by Indonesian Muslims, scholars and theologians at a seminar held in 1963 in Medan (North Sumatra), and reaffirmed in Aceh in 1978 (Kratz, 1988). Among others, the declarations made in this seminar are that Islam entered Indonesia for the first time in the $1^{\text {st }}$ century of hijrah $(7-8$ C.E.) and came directly from Arabia (Kratz, 1988). While there is perhaps evidence to support the claim that there was a community of Muslims in the Malay world as early as the $1^{\text {st }}$ century of hijrah (Groeneveldt, 1880), no conclusive hard evidence is available up to now to support this argument. A different approach from a Muslim scholar in the Malay world is that of Syed Muhammad Naquib al-Attas. Although he adopted a different approach in analizyng the issues of the coming of Islam to Malay world from those of the above faith-driven theoreticians, he came to a similiar conclusion, namely that Islam was brought to the Malay world from Arabia. He than added that is was brought largely, by the sayids, mainly from Hadramawt (Al-Attas, 1969).

Others, mainly western scholars on Islam in the Malay world, advanced with more caitious theories, restricted to search for and interpretation of hard evidence, limited and inconclusive as much as of it is, such as tombstone or the adherence of the Malays to a certain school of Islamic Jurisprudence (figh). Given the scarcity of hard evidence, various others theories relating to the provenance of Islam in the Malay world have emerged, which in the end have to be taken with equal caution, due to their tendency to overstate the general relevance of scattered evidences. we shall be discussing all of these theories in this article.

As we have mentioned before, the debate on the theories of Islamization of the Malay world evolves around three pertinent questions, namely when Islam was brought to the Malay world, by whom and how. Despite many attempts by scholars to answer those questions, this issues is yet to find conclusive answers. This is due to the absence of hard and convicing evidence to give overall support to any of the theories put forward to date. One of the reasons could be because some of the earliest written materials had been annihilated by the effect of tropical climate change throughout these long periods (Wheatley, 1961). This could be true if we look at the existence of the oldest known Malay manuscript, which was written in the second half of $14^{\text {th }}$ century C.E. in Palappo-Nusantaric script (Kozok, 2004). In the other words, no other textual evidence that has so far survived was written before that period in the Malay world. This could include data on the issues of Islamization of the Malay world.

However, before going into the discussion of the existing theories it is important to state the fact that clearly, these theories did not include any suggestion of the possible roles and contributions of the Malays themselves to the entire process of Islamization of their own land. This seems strange and needs to be looked at further.

There is evidence to show that the Malays, as coastal dwellers and seamen, were travelling, and probably also live outside the archipelago. Firstly, there is evidence written in the travalogue of Ibn Batuta during his travel to Asia to Africa between 1325 C.E. - 1354 C.E. Ibn Batuta documented in his book his encounter with the Malays in Ormuz at the Malabar coast and also even as far far as East Africa during his travels to these regions. Secondly, there is evidence as to the presence of the Malays in Gujarat. Nuruddin al-Raniri was recorded as having studied the Malay language during his early days in his hometown in Gujarat besides studying Islam, thanks to presence of a significant number of Malays in Gujarat at that time (Battuta, 1983). 
Thus, the presence of these Malays in Malabar regions, as well as Gujarat, which were recorded to have accepted Islam earlier than the Malay world and might be one of the places of origin of Islam in the Malay world, suggests that these Malays were Muslims as well. As seamen or probably merchants themselves, these Malays could possibly be involved together with other Muslims preachers, in bringing Islam to their homeland. Other than five pillars of Islam, there is no other important duty for a Muslims but to disseminate the message of Islam to those who are closest to themselves, as this is one of the fundamental teachings of Islam.

To continue with the discussions of the existing theories of Islamization of the Malay world, the earliest possible evidence on the presence of Muslims in the Malay world was documented by Chinese records in 674 C.E (Iskandar, 1966). It has been noted that this settlement headed by a chief, said to be an Arab, was found in East Sumatra. Another evidence on the early presence of Muslims in the archipelago is a massive emigration of Muslims traders and merchant said to be the Arabs and the Persians from Kanfu (Canton) to Kalah (Kedah) in 877 C.E. Al-Mas'udi recorded that this large scale of emigration was due to the decision made by the Chinese emperor at that time, Hi-Tsung to close the port in Canton to all foreign vessels, and to destroy foreign colonies in that region in order to contain local rebellion and prevent the rebels from getting assistance from outside the country (Groeneveldt, 1880).

Only after the $9^{\text {th }}$ century C.E. more evidence on the presence of the Muslims in the archipelago started to emerge in a different form. This is in the form of archacological evidence. One of the earliest tombstones belongs to a Muslim woman under the name of Fatima bint Maimun was found in Leran, Gresik, near Surabaya in East Java. The stone bears the date 1082 C.E (Al-Attas, 1969). Another tombstone was found in Samudra Pasai dated after conversion in 1297 C.E. This grave stone commemorates the founder of that state, Malik al-Saleh. A stone inscription written in arabic script, and constituting certain Islamics laws, was found in Kuala Berang, Trengganu on the eastern coast of the Malaysian peninsula (Fatimi, 1963). However, the date written on this stone is incomplete. As such, scholars have to use the incomplete information available on this stone to estabilish when it was written. Some scholars have concluded that this stone was written either in 1303. C.E. or 1386 C.E (Fatimi, 1963). Blagden is more inclined towards the latest possible date', which is on 2 February 1386 C.E (Peterson \& C.O. Blagden, 1924)., while al- Attas ascertains that this stone was written in 1303 C.E (Al-Attas, 1970). Thus, any interpretation given by these scholars has to remain in doubt as the evidence is incloncusive.

The visits of foreign travelers, Marco Polo in 1292 C.E. to Perlak in North Sumatra (Yule, 1929), Ibn Batuta in 1345 C.E. to Pasai (Battuta, 1983), and also Tome Pires's visit to Perlak as recorded in his book Suma Oriental in 1515 C.E (Cortesao, 1944) confirm that these areas were alredy penetrated by Islam. It may be concluded that Islam was present in the Malay world as early as the $7^{\text {th }}$ century C.E. However, the accelerating mode of the Islamization process began only by the end of the $13^{\text {th }}$ century C.E. onwards, especially after the establishment of the first Muslim kingdom in Samudra Pasai, according to the evidence we have today.

The discussion concerning the date of arrival of Islam in the Malay world did not attract much debate from scholars, compared to the issues of the origin of Islam in the archipelago. Scholars have shown their great interest in analyzing the question of the provenance of Islam, and put forward their arguments by relying on limited archaeological and circumstantial evidence, as well as local traditions, at hand.

Generally, these views are divided into three, namely that Islam came to the Malay world either from the Indian subcontinent, or from the Arabian peninsula or from China. Beside these three 
main origins of Islam in the Malay world, there is also another theory which suggest that Islam came from Egypt, but it has not gained much attention from scholars, probably because of the weak nature of the evidence put forward by its proponents. Scholars came out with different views after analyzing one or more of the following factors; the archaeological evidence, the adherence of the Malays to certain school of Islamic Jurisprudence, and also based on their analysis of the local customs and traditions, as well as relying on the history of trade and early relationship of the Malays with foreigners.

It is interesting, and yet strange, to note that none of these theories highlight the roles and contributions of the Malays themselves in the entire process of Islamization of their own land. Nevertheless, before coming up with some possible suggestions as to the roles and contributions of the Malays in this matter, it is worth reviewing the existing theories of the origin of Islam in the Malay world.

The Gujaratis theory is possibly the earliest theory put forward by scholars on question of the origin of Islam in the Malay world. This theory relies on the presence of archaeological evidence of early Muslims' tombstones found throughout the Malay world. Scholars such as Pijnappel quoted by Drewes (Drewes, 1968) and Moquette quoted by Azra (1992) proposed that Islam be brought to the Malay world by Muslims from Gujarat, the northen part of the Indian subcontinent. This conclusion was made after making camparison between tombstones found in Pasai and Gresik dated 1428 C.E. and 1219 C.E. respectively, and those found at Cambay, Gujarat at that time and the result was they were identical. This similarity prompted scholars to suggest that Gujarat could possibly be the place of origin of Islam in the Malay world.

This view is, however refuted by Marisson and later by Fatimi. Marisson argues that Gujarat cannot be the provenance of Islam, due to the fact that is was not only until 1928 C.E. that Gujarat was under the rule of Muslim's ruler (Marrison, 1951). Thus, according to him, it was not possible for Gujarat to have been an important base for Muslim missionaries to spread Islam to other areas. Marisson compared the school of law adhered to by the people of Gujarat and Samudra Pasai, which differed from one to the other. the former adopted either the Sunni Hanafiyyah School of Islamic Jurisprudence or shi'ism, while the latter adhered to the Sunni Shafiyyah School of Islamic Jurisprudence. Thus, he concluded that Muslims from southern India were actually responsible for bringing Islam to the Malay world, since there were similarities in terms of the school of law, as well as certain local traditions, which were portrayed in the Malay hikayats with the practice of people from south India at that time (Marrison, 1951).

Fatimi, on the other hand, contended that the tombstone found in Pasai was not identical with Gujarat but Bengal (Fatimi, 1963). He immediately concluded that Muslims from Bengal could be responsible for bringing Islam to the Malay world, based on available archaeological evidence. Fatimi also contested Marrison's view on the adherence of the Gujaratis as belonging to the Hanafi School of Islamic Jurisprudence. He maintained that most of the areas in Gujarat were as much Shafii Muslim as Coromandel and Malabar. This is evident with the background of one of the most popular Gujarati ulema (scholar) in the Malay world, Nuruddin al-Raniri, who proudly mentioned hid adherence to the Shafii school in his works (Fatimi, 1963).

Scholars who inclined towards the view of the South Asian origin came up with other supporting evidence as well. For example, van Ronkel (1922) and Snouck Hurgronje cited in Drewes (1968), and also Johns (1961) emphasized other circumstantial evidence such as the character of mysticism, the form of many Arabic loan words. The roles of Deccan Muslims as intermediaries in trade between the Arabian peninsula and the Malay world, who amongs them were the Sufis to 
support this theory. Therefore, Fatimi's theory of the Bengal origin would be unnaceptable if evaluated through this method, since the Bengalis's Muslims were known as adherents to the Hanafi School of Islamic Jurisprudence, and not to the Shafii's.

The discussions on the adherence of these early propagators of Islam to certain schools of Islamic jurisprudence brought the discussion to an origin in Arabia. For example, Niemman and Hollander, as cited in Hooker (1983), relied on the adherence to the Shafi'i school of Islamic jurisprudence among the population of the southern part of Arabian Peninsula as evidence to support this view. However, the main proponent for this theories Syed Muhammad Naguib al-Attas. We will be focusing more on his theory of the Islamization of the Malay world later. Since he came up with a theory which not only deals with the questions of the provenence of Islam, but also of the Islamization of the Malay world as dynamic process. Furthermore, he is the only scholar from the Malay world who has come out with a comprehensive theory of Islamization in the Malay world.

The debates of the origin of Islam in the Malay world have been given a new direction, away from ethnocentric theories to a boarder and wider perspective, focusing on the nature of Islam itself. Johns has developed an argument regarding the role of the Sufis in propagating and disseminating Islam to the entire Malay world, as the earliest group of Muslim preachers to do so (Johns, 1961). They might be the Sufis from the Middle East, Indian subcontinent or from any other part of Muslim world who had taken up this responsibility to spread Islam to the entire world. They came together with merchants on ships, with a mission to spread the religion to the local people. Interestingly, the ability of these Sufis to understand the local traditions made their efforts fruitful in bringing more people to Islam. They were able to convince the local people to adopt the Islamic teachings within the context of their existing traditional cultures dan practices. John's theory concludes that it was the Sufis who were responsible for the spread of Islam to the Malay world.

Al-Attas's theory of Islamization of the Malay world goes further in highlighting the dynamics of the entire process of Islamization. While older scholars were focusing on what he termed 'external' characteristics of Islam in analyzing the entire process of Islamization of the archipelago, he concentrates on the 'internal' characteristics of Islam as a religion in which according to him only Muslims understood best (Al-Attas, 1969). He started his theoretical propositions by saying that the notion that Islam came to the Malay world from India and was conveyed by 'Indians' as 'cannot be accepted' (Al-Attas, 1969). According to him, the suggetions that Islam came to the Malay world from India 'have been formulated to fit into the autochthonous theory' and 'have been based upon observation of merely the 'external' characteristics of Islam as revealed according to trade patterns, according to past experiences with Hinduism and Buddhism' (Al-Attas, 1969).

Furthermore, according to al-Attas, roughly from the $17^{\text {th }}$ century C.E. onwards, there was no evidence of a single South Asian author or work of South Asian origin found, and if there was any, as claimed by Western scholars they turned out to be Arab or Persian origins. Even what was most described as Persian has, in fact, been Arabian (Al-Attas, 1969). He then moved to say that the early missionaries to the Malay world were Arab or Arab Persian, based on their name and titles (Al-Attas, 1969). He admitted that some of these Arab missionaries came to the Malay world via India or China, but there were also those who came directly from Arabia (Al-Attas, 1969). He concluded his theory of origin of Islam in the Malay world from Arabia by emphasizing that 'most of the early missionaries were sayyids, many from Hadramawt, and the later missionaries of Islam in the archipelago were the Malays themselves and the Javanese and other indigenous people' (Al-Attas, 1969). Obviously, in his theory of origin of Islam in the Malay world the people from South Asia did not have a significant contribution to make to the entire process of Islamization of 
the Malay world. According to him, the subject of the provenance of Islam in the Malay world has been 'unduly magnified' with the role of India and the people from South Asia (Al-Attas, 1969).

Returning to al-Attas theory on the inner process of Islamization of the Malay world, he has divided this development into three phases, known as (i) the conversion of the body; (ii) the conversion of the spirit; and (iii) the period of continuation of the conversion of the body and the consummation of the conversion of the spirit (Al-Attas, 1969). The first phase, which occured approximately from the $13^{\text {th }}$ to $15^{\text {th }}$ centuries C.E., the Malays were introduced and converted to Islam by the strength of faith, and not necessarily accompanied by an understanding of the rational and intellectual implications such conversion entailed (Al-Attas, 1969). He continued by saying that 'fundamental concepts connected with the central Islamic concept of Unity of God (tawhid) were still vague in the minds of the converts, the old concepts overlapping and clouding or confusing the new ones (Al-Attas, 1969). In other words, al-Attas suggested that during these early periods of conversion to Islam, the Malays were simply converted to Islam without really understanding what Islam was all about. The Malays became Muslims, and were instructed to follow the religius laws (shariah) by the ulama i.e. the Arabs at that time. Islam has yet not penetrated the inner realm of the Malay at this stage.

It was only during the second phase of Islamization between the 15-18 th centuries C.E. that the Malays started to understand the inner meaning of Islam. According to al-Attas, Sufism and Sufi writings as well as the writings of the Mutakallimun played a dominant role at this stage in order to convert the spirit of the Malays (Al-Attas, 1969). The Malays began to understand the inner meaning of Islam, with the help of philosophical mysticism and metaphysics (tasawuf), and other rational and intellectual elements such as rational theology (kalam) (Al-Attas, 1969). Al-Attas termed the Malays before Islam as living in the world of mythology whilst when they became Muslims they were now living in the world of intelligence, reason and order (Al-Attas, 1969). AlAttas also stressed that Sufi metaphysics did not come 'to harmonize Islam with traditional beliefs grounded in Hindu-Buddhist beliefs and other authochthonous traditions as it was generally held even by some ulamas, but it came to clarify the difference between Islam and what the Malays had known in the past' (Al-Attas, 1969).

As for the third phase of Islamization, which started from the $18^{\text {th }}$ century C.E. and continued until today, al-Attas suggested that the Malays still continue the process of the first and the second phase i.e. the process of understanding and internalizing Islam as their new religions (Al-Attas, 1969). During this phase, the Malays faced cultural influences coming of the West. According to al-Attas, such influences were in fact laid earlier by Islam (Al-Attas, 1969).

\section{Analysis}

Several observations can be made. The hotly-debated issue on this matter among scholars concerns the provenance of Islam, as well as the carrier of Islam to the Malay world. Based on what we have highlighted before, theoreticians came from two main groups, based on the approach they were using to prove their cases.

The first group, the fact-based theorecitians, came to a conclusion regarding the issue of the provenance of Islam in the Malay world based on evidence gathered and interpreted from archeological and circumstantial evidence such as tombstones as well as the school of Islamic jurisprudence adhered to by local peoples found in the Malay world at that time. In general, they linked the provenance of Islam to the Indian subcontinent. However, they were also divided in terms of the exact location of the subcontinent either Gujarat, South India or Bengal. On the other 
hand, the South Arabian origin theory was only supported by the dominance of the Shafii's school of Islamic jurisprudence adhered to by the peoples of the Malay world, which can also be found in the southern part of the Arabian Peninsula. There are also views that the origins of Islam in the Malay world are to be found in China and Egypt. Although the proponents of these views claim to offer evidence for their theories, the nature of their evidence presented is puzzling and weak.

In order to avoid the complexities in substantiating such claims with hard and conclusive evidence, another theory was presented. This time, it eliminates the linking of the issue of provenance of Islam in the Malay world to any particular region or race, but goes beyond this by saying that it was the Sufis who were responsible in bringing Islam there. These Sufis could be from all parts of the Muslim world.

The second group, the faith-based theoreticians concluded that Islam was brought to the Malay world from Arabia. However, they did not offer any real evidence. Al-Attas, who is also of the view that Islam in the Malay world was brought directly from south Arabia, added further that it was a particular group the sayids who were responsible for this effort, without offering evidence to this either.

Furthermore, Al-Attas, as the only Muslim scholar who came out with views on how Islam was spread and received by the local peoples in three phrases, represents new insights and interesting to be discussed in the context of this study. His sole emphasis on the contribution of foreign Muslims i.e. the Arabs in bringing and disseminating Islam in the Malay world denies the contributions of local people in the entire process and especially at its early stages. Based on the evidence mentioned in the travelogues of Ibn Battuta on the presence of the Malays in Ormuz at the Malabar Coast and also even as far away as East Africa during his travels to these regions (Battuta, 1983), as well as the experience of Nuruddin al-Raniri who studied the Malay language with the Malays in Gujarat (Iskandar, 1966), there could be the possibility that these Malays were also involved in the process of bringing Islam to their homeland, and assisting foreign ulama in disseminating its teachings to the local peoples. Feener has also found evidence of elements of Malay Muslim tradition which had influenced diverse aspects of culture in southern Arabia and Wadi Hadramawt in particular as well as Arabic texts dating as far back as the fourteenth century on the exchanges between scholars of the two regions (Feener, 2009).

Beside, the discussions on the existing theories of Islamization of the Malay world, it is also important to highlight a study made by Russel Jones on the conversion of myths existing in the archipelago (Jones, 1979). These views could be used to understand the entire process of Islamization of the Malay world better. In his studies, Jones highlights that no identifiable author can be found for such myths, and that they were created 'by Muslims scribes under Muslim patronage, perhaps long after Islam had been accepted as a state religion (Jones, 1979). He found 'a kind of uniformity' about these myths which was characterized by miracles and other striking features such as dream or prediction. These, according to Jones, 'would have helped to soften the first impact of the change and to reconcile contradictions during the early transitional period' (Jones, 1979).

The above conclusion made by Jones after presenting various example of Islamization of the Malay world does agree with Al-Attas' top to bottom approach to the Islamization of the Malay world. In other words, these myths were created by the courts for a specific purpose which is that Islam was received by the rules directly from the descendants of the Prophet from Arabia. As such, this notion will help to convince people to accept Islam brought to them by their rulers, as this religion was perceived to be the most authentic form of Islam, because it was transmitted by 
the people who received it directly from the Prophet. Not only that, by doing so, the people would indirectly accept the legitimacy of the ruler, as it was in the past, because Islam also recognizes the authority of Muslim rulers as third in hierarchy after God and His Prophet, whom Muslims should obey as long as they rule in accordance with the teachings of Islam. Such a notion of a top to bottom approach of Islamization is also in line with the analysis made by Azra on what he termed 'local histories', such as in Hikayat Raja-Raja Pasai, Sejarah Melayu, Hikayat Merong Mahawangsa as well as the tarsilahs of the Muslim rulers of the Sulu Sultanante in the Philippines (Azra, 2006). He concludes his analysis by saying 'there are four main points conveyed by such local histories. First, Islam in the archipelago was brought directly from Arabia; second, it was introduced by 'professional' teachers or propagators ; third, the first converts were the rulers; and fourth, the most of these 'professional' preachers came to the archipelago in the twelfth and thirteenth centuries (Azra, 2006).

Riddell, in his studies on 'Islam and the Malay -Indonesian Worl', also put forward interesting findings relating to the dynamics of Islamization in the Malay world from the $13^{\text {th }}$ century C.E. up to the end of the last century. His studies, which mainly concentrated on the developmentof ideas by Malay Islamics writers, throughout these centuries, concluded that these ideas were originating from outside the Malay world (Riddell, 2001). Interestingly, according to him 'this did not merely take form of borrowing and imitation' (Riddell, 2001). In other words, although ulama in the Malay world depended on foreign ideas they did not simply take them as they were, without making necessary changes to suit the local context. These ulama according to Riddell 'have been impressed by contextualizing it to Malay circumstances, producing dynamics new result (Riddell, 2001).

He than gave an example of the ability of local ulamas to contextualize foreign ideas to match them to local needs. This is related to the 'ancient debates' in the Middle East on the relevationversus-reason between 'the more literalist group, the 'al-hadith', againts the approach adopted by the Mu'tazilite (Riddell, 2001), the rationalist whom relies on reason instead of relevation in order to understand theological issues in Islam such as 'creation, the world, and the nature of God' (Riddell, 2001). According to Riddell, 'in the Malay world the reverse order was the case' (Riddell, 2001). He then continued by saying that 'the battle between speculative Sufis and the Shari'aminded needed first to be resolved in the early centuries, and only then did the reason-versusrevelation debate assume priority during the 20 century when modernistsand traditionalist came face to face on centre stage' (Riddell, 2001). These unique developments, according to Riddell, show that not only the Malay Muslim in the Malay world owes much to other parts of Muslim worlds, but they themselves also 'made a substantial creative contribution to the mosaic of world Islam' (Riddell, 2001). Unlike Jones, Riddell's studies focus more on the ways Islam was received by the Malays. His findings seem to be in line with what we have indicated before, relating to the characteristics of the Malays as an advanced community, who are able to think for themselves for their own benefits. Riddell has shown that these Malays were able to adopt and adapt foreign influence to suit their own needs and interest.

\section{CONCLUSION}

The above discussions highlight one important finding which is the strong possibility of the contributions of the early Malays in the process of Islamization of the Malay archipelago. The abilities of these Malays to adopt and adapt foreign influences to suit their own needs and interest rejected the views that they were merely accepted anything introduced to them from outside the Malay world blindly. Thus, it would be interesting that the research on this issue is further expanded to find more evidence on the contributions of the early Malay to the entire process of Islamization of their own region. 


\section{References}

Al-Attas, S. M. N. (1969). Preliminary Statement on a General Theory of the Islamization of the Malay-Indonesian Archipelago, Kuala Lumpur. Kuala Lumpur: Dewan Bahasa dan Pustaka.

Al-Attas, S. M. N. (1970). The Correct Date of the Trengganu Inscription: Friday, 4 Rajab, 702 A.H./Friday, 22 February, 1303 A.C. Kuala Lumpur: Muzium Negara.

Azra, A. (1992). The Transmission of Islamic Reformism to Indonesia: Networks of Middle Eastern and Malay - Indonesian "Ulama" in the Seventeenth and Eighteenth Centuries. USA: Columbia University.

Azra, A. (2006). Islam in the Indonesian World: An Account of Institutional Formation. Bandung: Mizan Pustaka.

Battuta, I. (1983). Travels in Asia and Africa 1325-1354. (G. H.A.R., Trans.). London: Darf.

Cortesao, A. (1944). The SumaOriental of Tome Pires and The Book of Francisco Rodrigues. London: The Hakluyt Society.

Drewes, G. W. J. (1968). New Light on the Coming of Islam to Indonesia. BKI, 124, 439-440.

Fatimi, S. Q. (1963). Islam Comes to Malaysia. Singapore: MSRI.

Feener, R. M. (Ed.). (2009). Islamic Connections: Muslims Societies in South and Southeast Asia. Singapore: ISEAS.

Groeneveldt, W. P. (1880). Notes on the Malay World and Malacca Compiled from Chinese Sources. VBG, 39, 13-14.

Hooker, M. B. (Ed.). (1983). Islam in South-East Asia. Leiden: E.J. Brill.

Iskandar. (1966). Teuku, Nuru'd-din ar-Raniri Bustanu's-Salatin. Kuala Lumpur: Dewan Bahasa dan Pustaka.

Johns, A. H. (1961). Sufism as a Category in Indonesian Literature and History. JSEAH, 2(2), 10 23.

Jones, R. (1979). Then Conversion Myths from Indonesia. In N. Levtzion (Ed.), Conversion to Islam. London, New York: Holmes \& Meier Publishers Inc.

Kozok, U. (2004). The Tanjung Tanah Code of Law: The Oldest Extant Malay Manuscript. Cambridge: St Catharine's College and University Press.

Kratz, E. U. (1988). A Bibliography of Indonesian Literature in Journals: Drama, Prose and Poetry. Yogyakarta: Gadjah Madha University Press.

Marrison, G. E. (1951). The Coming of Islam to the East Indies. JMBRAS, 24(1), 32. 
Peterson, H. S., \& C.O. Blagden. (1924). An Early Malay Inscription from 14th century Terengganu. Journ. Mal. Br.R.A.S., 2, 258-263.

Riddell, P. (2001). Islam and the Malay-Indonesian World: Transmission and Responses. Singapore: Horizon Books Pte. Ltd.

Van Ronkel, P. S. (1922). A Tamil Malay Manuscript. JMBRAS, 85, 29.

Wheatley, P. (1961). The Golden Khersonese: Studies in the Historical Geography of the Malay Peninsula before A.D. 1500. Kuala Lumpur: Oxford University Press.

Yule, S. H. (1929). The Book of Ser Marco Polo. London: John Murray. 